\title{
Detection of Antibiotic-Producing Bacteria from Soil Samples in Parts of Wudil Local Governmemt Area Kano State, Nigeria
}

\author{
${ }^{* 1}$ Ismail, M. ${ }^{2}$ Ahmed, I. \\ ${ }^{1}$ Department of Microbiology and Biotechnology, \\ Faculty of Science, \\ Federal University Dutse, \\ P.M.B.7156, Jigawa State. \\ ${ }^{2}$ Department of Microbiology, \\ Faculty of Science, \\ Kano University of Science and Technology Wudil, \\ P.M.B. 3244, Kano State
}

Email: muslimismail1414@gmail.com

\begin{abstract}
The emergence of new diseases and multiple-antibiotic resistance pathogens that resist the action of clinically used antibiotics have increased the needs of discovering new antibiotics. However, soil served as the most important target for most researchers in their attempt of discovering new antibiotics that have pharmaceutical values. The aim of this study was to detect the antibioticproducing bacteria from soil samples in parts of Wudil local government of Kano state using standard procedure. The color ranged from light brown to dark brown. The texture ranged from clay loam, clay and loam. Sample $C$ was found to have the highest mean $p H$ and electrical conductivity of 7.46 and $108.90 \mu \mathrm{s} / \mathrm{cm}$, respectively, while sample $B$ had the least mean values of 6.95 and $73.53 \mu \mathrm{s} / \mathrm{cm}$, respectively. The highest mean bulk devsity and particle density was sample B with $1.60 \mathrm{~g} / \mathrm{cm}^{3}$ and $1.87 \mathrm{~g} / \mathrm{cm}^{3}$, respectively, while sample $C$ had the least mean values of $1.48 \mathrm{~g} / \mathrm{cm}^{3}$ and $1.71 \mathrm{~g} / \mathrm{cm}^{3}$, respectively. Sample $C$ was found to have the highest mean moisture content and porosity with $17.93 \%$ and $15.57 \%$, respectively, while sample $A$ had the least mean values with $10.61 \%$ and $10.74 \%$, respectively. Four bacterial spp. were identified based on morphological description, gram's reaction and biochemical tests, and were identified as Bacillus spp., Micrococcus spp., Pseudosomonas spp. and Proteus spp. Sample C was found to have the highest mean total bacterial viable plate count of $19.9 \times 10^{5} \mathrm{cfu} / \mathrm{g}$, while sample B had the least mean value of $4.1 \times 10^{5} \mathrm{cfu} / \mathrm{g}$. Bacillus spp. was found to have the highest percentage occurrence with 21(47\%), while Proteus spp. had the least value with $4(9 \%)$. E. coli had the highest and least susceptibility to metabolites produced by Bacillus spp. and Pseudosomonas spp. with inhibition zones of $(17$ and $0 \mathrm{~mm})$ respectively. While the control (Erythromycin $250 \mathrm{mg} / \mathrm{ml}$ ) produced the inhibition zones of $(27$ and $21 \mathrm{~mm})$ against E. coli and S. aureus respectively. It was concluded that soil samples in Lajawa, Kausani, Wudil Sabon gari and Wudil Tsohon gari of Wudil local government contained the bacteria with potentiality of producing antimicrobial substance and recommended the use of molecular techniques for further characterization.
\end{abstract}

Keywords: Antibiotics, Bacteria, The inhibition zone, Physicochemical, Soil 


\section{INTRODUCTION}

Soil is the major reservoir of antibiotic-producing microorganisms and served as a complex and very diverse environment that provide the versatile source of antibiotic-producing organisms. Several thousand antibiotics have been isolated from the soil organisms since the discovery of penicillin. The needs for new antibiotics grow day by day because of the emergence of multiple pathogens that are resistant to antibiotics treatments for formally life threatening diseases. Recent analysis showed that screenings of soil for the organism with antimicrobial activity have been carried out in many parts of the world (Makut and Owolewa, 2011). Statistical figures showed that each year, about 500 new antibiotics are found in which $60 \%$ of them are from the soil (Molinari, 2009). There is an increasing number of drug-resistant strains, mostly the acquired multi-drug resistant strains which is becoming serious public health problems worldwide. The consequence of misuse and over prescriptions of the antibiotics has affected the potentiality of the drugs to treat patients completely (Ruchika and Swernjeet, 2017). Antibiotics are the natural substance of biological, synthetic or semi-synthetic origin. It is playing an important role in the development of tissue culture techniques and basic screening, primarily in biochemistry, molecular biology, microbiology, genetics, pharmacology and organic chemistry. Soil microorganisms served as an inexhaustible reservoir of compounds with pharmacological, physiological, medical or agricultural applications. Most antibiotics used today are isolated from soil bacteria and recounted for their antibiotic production. Bacillus spp. being the common soil bacteria have been found inhibiting the growth of the many other organisms due of their resistant endospore formed and production of vital antibiotics such as bacteriocin. It is recomended to screen antibiotic-producing bacteria from the soil because they are easy to isolate, culture, maintain and increase the value of their strains (Singh and Mishra, 2013). The microbial populations in the soil depends on various factors such as soil type, water activity, oxygen, pressure, temperature, salt concentration, carbon sources, $\mathrm{pH}$ and other conditions. Antimicrobial agents play a crucial roles in the treatment of microbial infections and wide-spread efforts have been made by many scientists for the discovery of the novel antibiotic-producing microbes (Oskay and Tamer, 2004). Many antibiotics have been discovered to treat pathogenic organisms that cause infections.

Sharma et al. (2011) evaluated antimicrobial activity of soil bacteria against multi-resistant $S$. aureus and other pathogens. Out of 134 isolates, 51 showed antimicrobial activity against one or more test bacteria and 6 exhibited promising broad spectrum activity against all test bacteria. Vishwania (2007) isolated and identified Bacillus spp. and Micrococcus spp. from soil samples and was found to inhibit the growth of E. coli and S. aureus. Al-Harmesh (2018) isolated and idenfied Bacillus spp. from the soil samples and was found to have inhibition zones of $(18,15,20$ and $11 \mathrm{~mm})$ against E. coli, S. aureus, Klebsiella pneumonia and Pseudosomonas spp. respectively. Yunus et al. (2015) isolated Bacillus spp., Streptomyces spp. and Actinomyces spp. during their studies and were found to inhibit the growth of the test organisms. Muaz and Shahida (2010) also isolated Bacillus spp., Micrococcus spp., Proteus spp. and Pseudosomonas spp. from the soil samples and were found to inhibit the growth of E. coli and S. aureus.

This research work was undertaken to detect antibiotic-producing bacteria from soil samples in parts of the Wudil local government area of Kano state, Nigeria.

\section{MATERIALS AND METHODS}




\section{Study Area}

This research was conducted at Wudil local government of Kano state, Nigeria. Wudil local government area is located in the eastern part of Kano state between the latitude of $11^{\circ} 48^{\prime} 33.73^{\prime \prime} \mathrm{N}$ and longitude of $8^{\circ} 50^{\prime} 39.19^{\prime \prime} \mathrm{E}$ and at the elevation of 375 meters above sea level. It is bordered with Warawa to the west and north, Gaya to the east, Garko and Albasu to the South. The area has average rainfall of about $800-900 \mathrm{~mm}$ and annual temperature range between $26-33^{\circ} \mathrm{C}$. It covers the total area of about $640 \mathrm{~km}^{2}$ with about 23,066 population from 2006 census (Olofin, 2006). The main occupations of Wudil inhabitants are farming and trading.

\section{Sample Collection}

Soil samples were collected from 4 out of 10 wards of Wudil local government of Kano state as follows: Lajawa (lat. $11^{\circ} 52^{\prime} 35.04324^{\prime \prime} \mathrm{N}$, long. $8^{\circ} 55^{\prime} 16.93524^{\prime \prime} \mathrm{E}$ ), Kausani (lat. $11^{\circ} 50^{\prime} 15.2736^{\prime \prime} \mathrm{N}$, long. $8^{\circ} 54^{\prime} 0.30334^{\prime \prime} \mathrm{E}$ ), Wudil sabon gari (lat. $11^{\circ} 47^{\prime} 52.08^{\prime \prime} \mathrm{N}$, long. $\left.8^{\circ} 51^{\prime} 38.25^{\prime \prime} \mathrm{E}\right)$ and Wudil tsohon gari ward $\left(11^{\circ} 48^{\prime} 44.646^{\prime \prime} \mathrm{N}\right.$, long. $\left.8^{\circ} 51^{\prime} 14.502^{\prime \prime} \mathrm{E}\right)$ and labelled as A, B, C and D respectively. The total of 24 samples were collected using two different sampling procedures in each sampling point by systematic random sampling using zig zag pattern. In the first procedure the method of Smith (2000) was used, 12 samples were collected using core sampling techniques as follows: the surface soil to the depth of $2-5 \mathrm{~cm}$ was removed, the core sampler was hammered into the soil using hammer and helper. Adequate quantity of distilled water was added in the case of the dry soil. In the second procedure the method of Solanki and Chavda (2012) was used, here also 12 samples were collected directly at the same point to first sample using sterile polythene bag and spatula as follows: about $60 \mathrm{~g}$ of the soil from each sampling site was collected and placed into sterile polythene bag using sterile spatula. The samples were properly labeled as $\left(A_{1}-A_{3}, B_{1}-B_{3}, C_{1}-\right.$ $\mathrm{C}_{3}$ and $\mathrm{D}_{1}$-D3) and immediately transported to Soil Science and Microbiology laboratories, Kano University of Science and Technology Wudil for determination of physicochemical parameters and isolation of antibiotic producing bacteria respectively (Oranusi et al., 2013).

\section{Determination of Soil Physicochemical Parameters}

The method of Donald et al. (2002) was used in determining the color, texture, $\mathrm{pH}$, electrical conductivity, bulk density, particle density, moisture content and porosity. The mean of the 3 samples collected at each ward was then taken.

\section{Sample Preparation}

The method of Kaur et al. (2014) was used in preparing the samples. Firstly, the wet weight of the first samples contained within the core sampler were measured using weighing balance and recorded. The samples were then placed in to the hot air oven at $105^{\circ} \mathrm{C}$ for 3 days to dry. The second samples were allowed to air dry, after which they crushed using mortar and pestle and then passed through $2 \mathrm{~mm}$ aperture mesh to remove all the coarse and larger particles. The soil samples were serially diluted upto six fold (i.e 10-6).

\section{Sources of Test Organisms}

The method of Bala et al. (2012) was used for the collection of preserved culture of E. coli and $S$. aureus from the Microbiology laboratory of the Muratala Muhammad specialist hospital, Kano.

\section{Isolation of Bacteria with Antibiotic Activity from Soil Samples}


The method of Kavitha et al. (2017) was used for the bacterial isolation as follows: the nutrient agar (Life save biotech company, Trade St. San Diego, the USA) was prepared according to the manufacturer's specifications. Three sets of petri dish for each sample were labeled as $10^{-4}, 10^{-5}$ and $10^{-6}$. About $1 \mathrm{ml}$ of diluted samples from each test tube was dispensed aseptically into corresponding petri dish. $15 \mathrm{ml}$ of molten agar was poured into petri dishes, mixed gently and allowed to solidify. The plates were incubated at $37^{\circ} \mathrm{C}$ for 24 hours. After incubation, the total viable bacterial counts of the air-dried soil was conducted and recorded. All the plates were incubated again at $37^{\circ} \mathrm{C}$ for 72 hours. The soil bacteria that inhibited the growth of other bacterial colonies by producing inhibition zone were selected and subcultured on nutrient agar plate to obtain pure strain. The selected bacterial isolates were inoculated by spotting on the lawn culture plates of the test bacteria and incubated at $37^{\circ} \mathrm{C}$ for 24 hours, the one that produced inhibition zones around test bacteria were stored as stock culture in nutrient agar slant at $4^{\circ} \mathrm{C}$ for further usage.

\section{Identification of the Bacterial Isolates with Antibiotic Activity}

The method of Baltz (2006) was used for the identification of the bacterial isolates. The identification was based on morphological description of colonies, Gram's reaction and biochemical tests and the results were compared with the standard description given in Bergey's manual of systematic bacteriology. The chemical tests performed were catalase, coagulase, citrate, sugar fermentation, methyl red, Voges-proskauer and motility test.

\section{Antimicrobial Screening}

The method of Abdulmumin et al. (2019) was used for determination of the antibacterial activity of the bacterial isolates. The agar well diffusion method using Muller-Hinton Agar (Sigma-Aldrish Chemi GmbH company, Buchs) was used. Cell concentration of 0.5 McFarland standard of all the test bacteria were inoculated in Muller-Hinton agar plates using sterilized cotton swabs. The sterile cork borer was used to bore the wells. About $0.1 \mathrm{ml}$ of the bacterial isolates and Erythromycin $(250 \mathrm{mg} / \mathrm{ml})$ as control was introduced into the wells. The plates were incubated at $37^{\circ} \mathrm{C}$ for 24 hours and inhibition zones were observed and measured.

\section{RESULTS}

Table 1 showed results for the mean physicochemical parameters of soil samples. The color ranged from light brown to dark brown. The texture ranged from clay loam, clay and loam. Samples $\mathrm{C}$ and $\mathrm{D}$ were found to have the highest mean $\mathrm{pH}$ and mean electrical conductivities of $7.46,7.37,108.90 \mu \mathrm{s} / \mathrm{cm}$ and $105.90 \mu \mathrm{s} / \mathrm{cm}$, respectively, while samples A and $\mathrm{B}$ had the least mean $\mathrm{pH}$ and mean electrical conductivities $7.36,6.95,79.40 \mu \mathrm{s} / \mathrm{cm}$ and $73.53 \mu \mathrm{s} / \mathrm{cm}$, respectively. Samples B and A were found to have the highest mean bulk density and mean particle density of $1.60 \mathrm{~g} / \mathrm{cm}^{3}, 1.58 \mathrm{~g} / \mathrm{cm}^{3}, 1.87 \mathrm{~g} / \mathrm{cm}^{3}$, and $1.81 \mathrm{~g} / \mathrm{cm}^{3}$, respectively, while samples $\mathrm{D}$ and $\mathrm{C}$ had the least mean bulk density and mean particle density of $1.50 \mathrm{~g} / \mathrm{cm}^{3}, 1.48 \mathrm{~g} / \mathrm{cm}^{3}, 1.75 \mathrm{~g} / \mathrm{cm}^{3}$ and $1.71 \mathrm{~g} / \mathrm{cm}^{3}$, respectively. Samples C and D were found to have the highest mean moisture content and the mean porosity with $17.93 \%$, $13.05 \%, 15.58 \%$ and $13.89 \%$, respectively, while samples $\mathrm{B}$ and $\mathrm{A}$ had the least mean moisture contents and mean porosity of $12.77 \% 10.61 \%, 12.69 \%$ and $10.74 \%$, respectively.

\section{Table 1: Mean Physicochemical parameters of Soil Samples}




\begin{tabular}{|c|c|c|c|c|c|c|c|c|}
\hline$\overline{\mathrm{SC}}$ & Color & Texture & $\begin{array}{l}\mathrm{pH} \\
(\mu \mathrm{s} / \mathrm{cm})\end{array}$ & $\begin{array}{l}\mathrm{EC} \\
\left(\mathrm{g} / \mathrm{cm}^{3}\right)\end{array}$ & \multicolumn{2}{|c|}{$\begin{array}{l}\text { BD PD } \\
\left(\mathrm{g} / \mathrm{cm}^{3}\right)\end{array}$} & $\begin{array}{r}\text { MC } \\
(\%)\end{array}$ & $\begin{array}{c}\text { Porosity } \\
(\%)\end{array}$ \\
\hline $\bar{A}$ & $\begin{array}{l}\text { Light } \\
\text { brown }\end{array}$ & $\begin{array}{l}\text { Clay } \\
\text { loam }\end{array}$ & 7.36 & 79.40 & 1.5 & 1.81 & 10.61 & 10.74 \\
\hline B & $\begin{array}{l}\text { Light } \\
\text { brown }\end{array}$ & Clay & 6.95 & 73.53 & \multicolumn{2}{|c|}{1.601 .87} & 12.7712 .69 & \\
\hline C & $\begin{array}{l}\text { Dark } \\
\text { brown }\end{array}$ & Loam & 7.46 & 108.90 & 1.48 & 1.71 & 17.93 & 15.57 \\
\hline D & $\begin{array}{l}\text { Dark } \\
\text { brown }\end{array}$ & Loam & 7.37 & 105.90 & 1.50 & 1.75 & 13.05 & 13.89 \\
\hline
\end{tabular}

$\mathrm{A}=$ Lajawa, $\mathrm{B}=$ Kausani, $\mathrm{C}=$ Wudil Sabon gari, $\mathrm{D}=$ Wudil Tsohon gari $\mathrm{SC}=$ Sample codes, $\mathrm{EC}=$ Electrical conductivity, $\mathrm{BD}=$ Bulk density, $\mathrm{PD}=$ Particle density, $\mathrm{MC}=$ Moisture content.

ANOVA $\mathrm{P}<0.05$, degree of freedom column $=5,15$, degree of freedom row $=3,15$, Fvalue column= 2.90, Fvalue row $=3.29$, calculated Fcolumn $=5.14$, calculated Frow $=4.19$.

The results for the morphological and biochemical identification of the bacterial isolates (Table 2). Four bacterial spp. were isolated and identified based on morphological description, gram's reaction and biochemical characterization as compared with standards such as catalase, coagulase, methyl red, Voges-proskauer, sugar fermentation and motility tests. Bacillus spp., Micrococcus spp., Pseudosomonas spp and Proteus spp. were obtained.

Table 2: The morphological and biochemical identification of the bacterial isolates

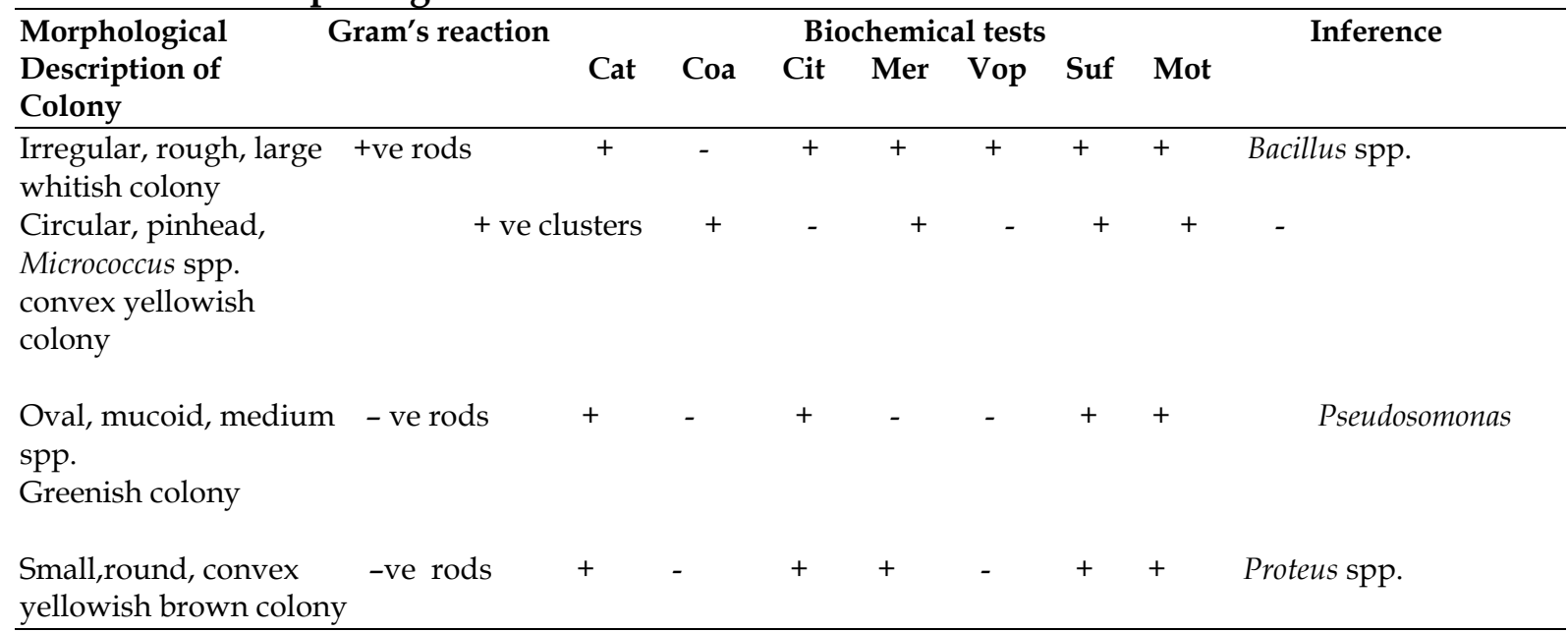

Cat $=$ Catalase test, $\mathrm{Coa}=$ Coagulase test, $\mathrm{Cit}=$ Citrate test, Mer= Methyl red test, Vop $=$ Voges-proskauer test, Suf $=$ Sugar fermentation test, Mot= Motility test, $-=$ Negetive result and $+=$ Positive result.

Table 3 showed results for the mean total viable bacterial counts of bacterial isolates per gram of soil samples. Samples $C$ and D were found to the have highest mean total viable bacterial counts with $19.9 \times 10^{5} \mathrm{cfu} / \mathrm{g}$ and $17.6 \times 10^{5} \mathrm{cfu} / \mathrm{g}$, respectively, while samples A and B had the least mean total viable bacterial count of $4.2 \times 10^{5} \mathrm{cfu} / \mathrm{g}$ and $4.1 \times 10^{5} \mathrm{cfu} / \mathrm{g}$, respectively. 


\begin{tabular}{|c|c|}
\hline Sample codes & Mean bacterial viable plate counts (cfu/g) \\
\hline $\mathrm{A}$ & $4.2 \times 10^{5}$ \\
\hline B & $4.1 \times 10^{5}$ \\
\hline $\mathrm{C}$ & $19.9 \times 10^{5}$ \\
\hline $\mathrm{D}$ & $17.6 \times 10^{5}$ \\
\hline
\end{tabular}

Table 4 showed results for the percentage occurrence of bacterial isolates with antibiotic activity. Bacillus spp. was found to the have highest percentage of occurrence with $21(47 \%)$, while Proteus spp. had the least percentage of occurrence with $4(8.89 \%)$.

Table 4: Percentage occurrence of bacterial isolates with antibiotic activity

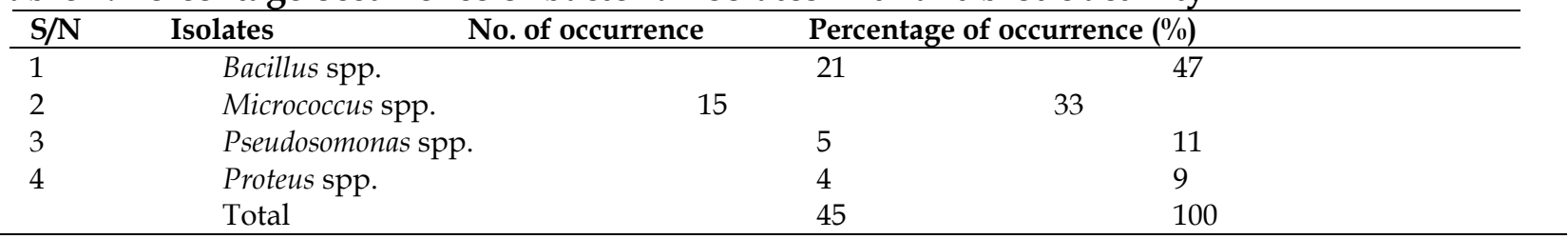

Results for antimicrobial activity of bacterial isolates against E. coli and S. aureus (Table 5). E. coli had the highest and least susceptibility to metabolites produced by Bacillus spp. and Pseudosomonas spp. with inhibition zones of $(17$ and $0 \mathrm{~mm})$ respectively. While the control (Erythromycin $250 \mathrm{mg} / \mathrm{m}$ ) produced the inhibition zones of (27 and $21 \mathrm{~mm}$ ) against E. coli and $S$. aureus respectively.

Table 5: Antimicrobial activity of bacterial isolates against E. coli and S. aureus

\begin{tabular}{|c|c|c|c|}
\hline $\mathrm{S} / \mathrm{N}$ & Bacteria isolates & Zones of inhibition (mm) & \\
\hline & & E. coli & S. aureus \\
\hline 1. & Bacillus spp. & 17 & 6 \\
\hline 2. & Micrococcus spp. & 11 & 5 \\
\hline 3. & Pseudosomonas spp. & 0 & 7 \\
\hline 4. & Proteus spp. & 14 & 5 \\
\hline 5. & Erythromycin $(250 \mathrm{mg} / \mathrm{ml})$ & 27 & 21 \\
\hline
\end{tabular}

\section{DISCUSSION}

The statistical analysis of mean physicochemical parameters of the soil samples using ANOVA $(p<0.05)$ showed that there is a significant difference between the soil samples in parts of Wudil. The variation in $\mathrm{pH}$, electrical conductivity, moisture content and porosity might be due to soil color and texture of the soil samples. This was in agreement with findings of Rousk et al. (2010) that showed neutral to alkaline $\mathrm{pH}$ as the favorite condition for bacterial growth and mostly in neutral $\mathrm{pH}$, bacterial growth has positive correlation with diversity, richness, bacterial community, and composition of soil bacteria. There are many aspects that influence the soil bacterial population and activity, soil $\mathrm{pH}$, color and texture are the most significant property of the soil which affect soil electrical conductivities, particle density, moisture content and organic contents. Smita and Sangita (2015) stated that soil electrical conductivity is a important property that influences the growth and distribution of soil bacteria, and the electrical conductivity of the soil increase with increased concentration of ions. Casanova et al. (2016) stated that soil bulk density is an determinant of soil particle density, porosity and moisture content and it is dependent on soil texture and structure.

The bacterial isolates obtained during the research (Table 2) might be due to the fact that, these bacterial isolates have genetic potential of producing an antimicrobial substances that inhibit the growth of their neighbouring susceptible bacteria.This was in agreement to the findings of Ahmad et al. (2013) that isolated and identified Bacillus spp., Proteus spp., Micrococcus spp. and Pseudomonas spp. and were found inhibit the growth of E. coli, S. aureus 
and other test bacteria. Also, Bala et al. (2012) isolated and identified bacterial species with antibiotic activity in their research, the bacterial isolates were identified as Bacillus spp. and Pseudomonas spp. and were found to inhibit the growth E. coli, S. aureus and Salmonella spp. The results obtained for mean total viable bacterial counts (Table 3) might be due to soil color, texture, electrical conductivity, moisture content and porosity. This was in agreement with the findings of faith et al. (2010) who stated that variation in the bacterial load of the soil might be due to soil color, composition, $\mathrm{pH}$, electrical conductivity, moisture content and porosity, and his result revealed that Bacillus spp., Micrococcus spp. and Pseudosomonas spp. with antibiotic properties were present in the soil samples screened. The results obtained for the percentage of occurrence of bacterial isolates with antibiotic activity (Table 4) might be due to the fact that Bacillus spp. had potential resistant endospores that enable them survive unfavorable environmental conditions of the soil. This was in agreement with findings of Gopi (2011) who reported Bacillus spp. as the predominant soil bacteria due to their resistant endospore formation and their ability to produce antibiotics of medical importance. Prescott et al. (2008) stated that, the spore forming bacteria and other members of the Bacillus genus possesses genes for the catabolism of the diverse carbon source and antibiotic synthesis, and reported bacitracin and subtilin produced by Bacillus spp. discovered during their study inhibited E. coli and S. aureus.

The results for antimicrobial activity of bacterial isolates against test bacteria (Table 5) might be due to the genetic potential of the bacteria with antibiotic activity of producing antimicrobial metabolites that inhibit the growth of other neighbouring susceptible bacteria. This was in agreement with findings of Al-Harmesh, (2018) who isolated and identified Bacillus spp. from soil samples and was found to have the inhibition zones of $(18,15,20$ and $11 \mathrm{~mm}$ ) against E. coli, S. aureus, Klebsiella pneumonia and Pseudosomonas spp. respectively. Pandey et al. (2011) also isolated and identified Bacillus spp., Micrococcus spp., Proteus spp. and Micromonospora spp. from the soil and evaluated their antimicrobial activity against $S$. aureus, E. coli, S. typhi and K. kneumoniae and were found to inhibit the growth of all the test bacteria. Gayathri et al. (2011) isolated and identified Bacillus spp. from the soil habitat that posses the zone of inhibitions of $(18$ and $5 \mathrm{~mm})$ against $E$. coli and $S$. aureus respectively.

\section{CONCLUSION}

The study revealed that, bacteria with the potentials to produce antibiotics were present in the soil under consideration. Despite the fact that, there is large list of antibiotics commercially available, this work may contribute in exploring a number of microorganisms from the soil that are producing antimicrobial substance as an alternative that help in reducing the menace of antibiotic resistance. Screening of antibiotics have been widely performed for about last 50 years and new antibiotics are still being formed. It can be concluded that based on statistical analysis on physiochemical parameters using ANOVA, there is a significant difference between physicochemical parameters of soil samples screened. The bacteria with antibiotic activity isolated in this study were: Bacillus spp., Micrococcus spp., Pseudosomonas spp. and Proteus spp. and were found to inhibit the growth of E. coli and S. aureus.

\section{RECOMMENDATIONS}

It was recommended that the further strain improvement of the bacteria with antimicrobial activity should be encouraged to improve the productivity. Modern equipment and machinery should be employed for effective extraction and purification of antibiotics. Further investigation regarding characterization of the bacteria with antibiotic activity should be done using molecular techniques. 


\section{RFERENCES}

Abdulmumin, A.R., Kassim, Z.J., Muhammad, I.L., Mohammed, S.B. and Ya'aba, Y. (2019). Antimicrobial Potency and Bioactive gredients of Different Extracts of Prosopis africana against Some Selected Human Pathogenic Microbes: An In-vitroApproach, Journal of Complementary and Alternative Medical Research, 8(1): 1-9.

Ahmad, N., Sani, A.H., Ajijokolokewu, F. and Alamu, F.B. (2013). Screening for Antibiotic Producing Microorganisms, Advances in Environmental Biology, 7(1): 7-10.

Al-Harmesh, R. (2018). Isolation and Identification of Antibiotic Producing Bacteria from Local Soil in Babylon province, Eupharate Journal of Agricultural Science, Second Veterinary Conference, 304-310.

Bala, J.D., Abioye, O.P., Auta, A.S., Damisa, D., Kuta, F.A., Adabara, N.U. and Udenyi, E.O. (2012). Isolation and identification of soil bacteria with potential to produce antibiotics, Journal of Research in Biosciences, 6(13): 361-364.

Baltz, R.H. (2006). Marcel Faber Roundtable, is our antibiotic pipeline unproductive because of starvation, constipation or lack of inspiration? Journal of Industrial Microbiology and Biotechnolog, 33(7): 507-513

Casanova, M., Tapia, E., Seguel, O. and Salazar, O. (2016). Direct measurement and predictionof bulk density on alluvial soils of central Chile, Chilean Journal of Agricultural Resident, 76: 105-113.

Donald, R.C., Isbell, R.F., Speight, J.G., Walker, J. and Hopkins, M.S. (2002). Australian Soil and Land Survey Field Handbook, Australian Collaborative Land Evaluation Program: Canberra, 35-42.

Faith, O.E., Christopher, U.A. and Uyiosa, G.L. (2010). Archive of Applied Science Research, 2(5): 161-167.

Gayathri, A., Madhanraj, P. and Pannerselvam, A. (2011). Diversity, antibacterial activity and molecular characterization of antibiotic producing bacteria isolated from salt pan region of Kodiakarai, Nagapattinam, Asian journal of pharmaceutical technology, 1(3): 79- 81.

Gopi, K.D. (2011). Isolation and identification of soil bacteria with potential to produce antibiotics, Journal of Pharmcognosy, 10: 32

Kaur, S., Kaur, J. and Pankaj, P.P. (2014). Isolation and characterization of antibiotic producing microorganisms from soil samples of a certain area of Punjab region of India. International Journal of Pharmaceutical and Clinical Research. 6(4): 312-521.

Kavita, R., Amodharan, N. and Dhivya, C. (2017). Screening, Isolation and Antibacterial Activity of Antibiotic Producing Bacteria Obtained from Saprophytic Soil Samples, Asian Journal of Pharmaceutical and Clinical Research, 10(3): 92-96.

Makut, M. and Owolewa, O. (2011). Antibiotic-producing fungi present in the soil environment of Keffi metropolis, Nasarawa state, Nigeria, Eubacteria. 10(18):19

Molinary, M. (2009). The influence of natural products upon drug discovery, Natural Product Reports, 5(3): 215-34.

Muaz, M.A. and Shahida, H. (2010). Bacteria Exhibiting Antimicrobial Activities: Screening for Antibiotics and the Associated Genetic Studies, The Open Conference Proceedings Journal, 1: 230-238.

Olofin, S. O., (2006). Preliminary Thoughts on Nigeria Case Study, Paper presented at the Conference on Southern Perspectives on Reform of the International Development Architecture, held at Strathmere, Ottawa, Canada, 15 - 17. 
Oranusi, S., Oniyeike, E., Galadima, M. and Umoh, V.J. (2013). Hazard analysis critical control points of foods prepared by family in Zaria, Nigeria. Nigerian Journal of Microbiology, 18(12): 346-362.

Oskay, M., Tamer, A.U. and Azeri, C. (2004). African Journal of Biotechnology; 3(9): 441- 446.

Pandey, A., Ali, I. Butola, K.S., Chattaji, T. and Sing, V. (2011). Isolation and characterizationof antibiotic producing bacteria from soil and evaluation of their antimicrobial activity against human pathogens, International journal of applied biology and pharmaceutical technology, 2(4): 384-392.

Prescott, M.L., Harley, P.J. and Klein, A.D. (2008). Microbiology, 7th edition, 42-51, 232-233, 762-764.

Rousk, J., Baath, E., P. C. Brookes, P.C., Lauber, C.L., Lozupone, C., Caporaso, J.G., Knight, R. and Fierer, N. (2010). Soil bacterial and fungal communities across a $\mathrm{pH}$ gradient in an arable soil, International Society for Microbial Ecology, 1-12.

Ruchika, S. and Swarnjeet, K. (2017). Antimicrobial and phytochemical screening of trikuta traditional food of western Rajasthan, Indian Journal of Traditional Knowledge, 16: 270276.

Sharma, D., Kaur, T., Chadha, B.S. and Manhas, R.K. (2011). Antimicrobial activity of soil bacteria against multi resistant Staphylococcus aureus, Escherichia coli and other pathogens, Tropical journal of pharmaceutical research, 10(6): 801-808.

Singh, A.P. and Mishra, S. (2013). Isolation and biochemical characterization of antibiotic producing microorganism from waste soil samples of certain industrial areas of India. Scientific Research Journal of Pharmaceutical Biological Science, 5(6): 80-89.

Smita, T. and Sangita, I. (2015). A Review on Role of Physicochemical Properties in Soil Quality, Chem. Sci. Rev. Lett., 4(13): 57-66.

Smith, K.A. (2000). Soil and Environmental Analysis: Physical Methods, Revised, and Expanded, CRC Press, New York, 5-7.

Solanki, H.A. and Chavda, N.H. (2012). Physicochemical analysis with reference to seasonal changes in soils of Victoria park reserve forest, Bhavnagar (Gujarat), 109-12.

Vishwakarma, R. (2007). Isolation, Identification, Purification and Characterization of Antibiotic Producing Bacteria from Different Soil Samples, International Journal of Advance Research, Ideas and Inovationin Technology, 3(5): 201-203.

Yunus, F.N., Khalid, Z.Z., Rashid, F., Ashraf, A., Iqbal, M.N. and Hussain, F. (2016). Isolation and Screening of Antibiotic Producing Bacteria from Soil Samples in Lahore city, PSM Microbiology, 1(1): 01-04. 